\title{
CUMPRIMENTO DE SENTENÇA EM FACE DA FAZENDA PÚBLICA E GARANTIA FUNDAMENTAL À TUTELA EXECUTIVA EFETIVA E EM TEMPO RAZOÁVEL: UMA SITUAÇÃO A SER SUPERADA
}

\author{
JUDGEMENT COMPLIANCE IN THE FACE OF THE PUBLIC TREASURY AND \\ FUNDAMENTAL GUARANTEE TO EFFECTIVE AND TIMELY EXECUTIVE \\ TUTELAGE: A SITUATION TO BE OVERCOME
}

Fabrício de Farias Carvalho ${ }^{1}$

\section{RESUMO}

$\mathrm{O}$ artigo intenta investigar a existência da garantia processual fundamental à tutela executiva efetiva e tempestiva como corolário do modelo constitucional de processo. A partir do reconhecimento de tal garantia, analisa-se a sistemática de execução contra a Fazenda Pública no CPC/2015, em confronto com o regramento anterior. Considerando a produção doutrinária e jurisprudencial - antes e depois do CPC/2015 -, constata-se a necessidade de proceder-se a uma (re)leitura de posicionamentos doutrinários e jurisprudenciais acerca do citado procedimento a fim de realizar tal garantia, notadamente a possibilidade de prosseguimento da execução após a rejeição da impugnação, ainda que na pendência de recurso.

Palavras-chave: Execução. Garantias fundamentais. Efetividade. Tempestividade. Fazenda Pública.

\begin{abstract}
This paper aims to investigate the existence of the procedural guarantee that is fundamental to effective and timely executive tutelage as a corollary of the constitutional procedural model. From the recognition of such guarantee, it analyzes the system of execution against the Public Treasury in $\mathrm{CPC} / 2015$, in comparison to the previous rule. Regarding the doctrinal and jurisprudential production, both before and after CPC/2015, there is a need for (re)reading the doctrinal and jurisprudential positions on the procedure mentioned, in order to effectuate such guarantee, particularly the possibility of proceeding with the execution after the impugnation is rejected, in spite of the pending appeal.
\end{abstract}

Keywords: Execution. Fundamental guarantees. Effectiveness. Timing. Public Treasury.

\footnotetext{
${ }^{1}$ Doutorando em Direito pela Universidade Estácio de Sá/RJ. Mestre em Direito pela PUC/RS. Professor de graduação e pós-graduação lato sensu do Centro Universitário Santo Agostinho/PI. Advogado. Endereço postal: Rua Coelho Rodrigues, 1999, Sala 207, Centro, Teresina - PI, CEP: 64.000-080. E-mail: fabriciofcarvalho@gmail.com.
} 
Fabrício de Farias Carvalho

\section{INTRODUÇÃO}

Lição indispensável ao estudo do Código de Processo Civil de 2015 (L. 13.105/2015, art. $1^{\circ}$.) - CPC/2015 - é a percepção de que o diploma legal primou por consagrar o fenômeno que a doutrina convencionou chamar de constitucionalização do processo, caracterizado pela irradiação de normas e valores constitucionais para todo o ordenamento jurídico infraconstitucional, assim como pela absorção, no texto constitucional, de normas com evidente conteúdo processual.

Ao estampar no art. $4^{\circ}$ que "As partes têm o direito de obter em prazo razoável a solução integral do mérito, incluída a atividade satisfativa”, o CPC/2015 alçou ao patamar de norma processual fundamental a garantia de uma tutela executiva efetiva e tempestiva, que pode ser extraída das garantias fundamentais de acesso à Justiça e duração razoável do processo (art. $5^{\circ}, \mathrm{XXXV}$ e LXXVIII, CF/88), considerando que efetividade e tempestividade não poderiam ficar adstritas ao processo de conhecimento/fase cognitiva.

Nessa esteira, o presente artigo se propõe a analisar, sem pretensão de exaustão, a citada garantia processual, bem como sua densificação legislativa no Código de Processo Civil de 2015, em cotejo com o sistema revogado, analisando seu impacto no procedimento de cumprimento de sentença pecuniária em face da Fazenda Pública, levantando-se o que já existe de construção doutrinária e jurisprudencial, de modo a contribuir para os primeiros delineamentos interpretativos dos novéis dispositivos, assim como a superação de alguns dogmas procedimentais, a exemplo da necessidade do trânsito em julgado da decisão de rejeição da impugnação ao cumprimento de sentença para continuidade da execução por quantia certa fundada em título judicial.

Para tanto, distribuiu-se o tema em dois tópicos, defendendo-se, no primeiro, a existência de uma garantia fundamental à tutela executiva efetiva e prestada em tempo razoável. No segundo tópico abordou-se a sistemática do cumprimento de sentença que condena ao pagamento de quantia certa em face da Fazenda Pública, realizando-se o necessário cotejo com o regramento do Código de Processo Civil de 1973 - CPC/1973 buscando, ao final, traçar algumas balizas interpretativas ante a necessidade de superação de 
alguns posicionamentos arraigados na doutrina e jurisprudência pré-CPC/2015 que, no contemporâneo modelo constitucional de processo, não mais devem subsistir.

Esclareça-se, por oportuno, que em razão da limitação temática do presente estudo, não serão abordados o conteúdo da Constituição Federal acerca da execução contra a Fazenda Pública, nem tampouco a execução de título extrajudicial e a sistemática de cumprimento de sentenças que condenam em obrigação de fazer, não fazer e entregar.

\section{GARANTIA FUNDAMENTAL À TUTELA EXECUTIVA EFETIVA E EM TEMPO RAZOÁVEL}

Há muito já não se concebe mais o acesso à justiça, ou direito ao processo, como mero direito de se dirigir ao Poder Judiciário ou apresentar uma defesa em juízo. Como efeito inafastável do monopólio da jurisdição pelo Estado, este assumiu a função de solução integral dos conflitos, exercida por meio do processo e disponibilizada aos indivíduos por meio do direito de ação, consagrado no art. $5^{\circ}$., XXXV, da Constituição Federal.

Ocorre que tal resposta estatal não pode vir de qualquer forma e a qualquer tempo, a pretexto de tão somente solucionar o conflito declarando o vencedor. É imperioso que a tutela jurisdicional também seja apta a realizar praticamente os direitos, em tempo hábil de ser gozado satisfatoriamente, sob pena de se declarar direitos fundamentais sem efetivamente os proteger, esvaziando, igualmente, a própria dignidade jurídico-constitucional dos direitos e garantias fundamentais.

Prevista no artigo $5^{\circ}$, LXXVIII, da Constituição Federal, a garantia da razoável duração do processo e os meios que garantam a celeridade de sua tramitação asseguram aos litigantes, seja em processo judicial, seja administrativo, uma razoabilidade na administração do tempo de tramitação do seu processo, seja em relação aos atos processuais isoladamente considerados, seja quanto ao resultado final da demanda. Dessa forma, a jurisdição prestada pelo Estado deve ser proporcionada em tempo razoável, por imposição constitucional.

Com o mesmo desiderato, o CPC/2015 alocou no rol de normas fundamentais do processo civil a duração razoável, corroborando, agora também em nível infraconstitucional, sua fundametalidade. É o que se extrai do arts. 4". ("As partes têm o direito de obter em prazo razoável a solução integral do mérito, incluída a atividade satisfativa") e $6^{\circ}$. (“Todos os 
sujeitos do processo devem cooperar entre si para que se obtenha, em tempo razoável, decisão de mérito justa e efetiva").

Insta ressaltar, ainda, que apesar de a doutrina quase sempre se referir ao processo de conhecimento $^{2}$ quando fala da necessária tempestividade da prestação jurisdicional, não restam dúvidas que a efetivação em sentido estrito, como trabalhado no item anterior, seja por meio do processo de execução, seja por meio da fase de cumprimento, também encerra a ideia de processo e, portanto, é credora de uma razoável duração, nos exatos termos prometidos pelo constituinte.

Sobre o tema Nicolitti (2014, p. 59) afirma, na linha da jurisprudência do Tribunal Europeu de Direitos Humanos, que pouco importa se o ordenamento interno fragmenta o processo em fases ou divide processo de conhecimento de processo de execução, uma vez que a CF/88 fala em processo, pura e simplesmente, e conclui "Não se tem dúvida que a natureza do processo de execução é de processo, por consequência, o processo de execução está coberto pela garantia da duração razoável, mesmo porque, pouco importa ver declarado o direito se não puder usufruir do mesmo".

Em sede infraconstitucional, o novo Código de Processo Civil brasileiro, instituído pela Lei n. 13.105/2015, parece apreender as ideias aqui esposadas, ao dispor expressamente, no art. $4^{\circ}$, que: "As partes têm o direito de obter em prazo razoável a solução integral do mérito, incluída a atividade satisfativa", englobando de forma expressa a necessidade de que também a fase de cumprimento/execução dos provimentos judiciais, quando for o caso, se desenvolvam em tempo razoável.

De outro norte, ante a inexistência de previsão constitucional expressa e objetivando preencher qualquer espaço para dúvidas (apesar da tranquila aceitação de uma grantia fundamental implícita da efetividade), o novo Código de Processo Civil aponta como uma das normas processuais fundamentais a efetividade da prestação jurisdicional, que pode ser extraída do já citado art. $6^{\circ}$, in verbis, "todos os sujeitos do processo devem cooperar entre si para que se obtenha, em tempo razoável, decisão de mérito justa e efetiva".

Nesse sentido é a lição de Greco (2012, p. 274)

\footnotetext{
${ }^{2}$ Marinoni (2007a, p. 11), por exemplo, ao debater sobre a tempestividade da tutela jurisdicional, aduz que "um dos grandes desafios - talvez o maio - da processualística moderna é conciliar o direito à tempestividade da tutela jurisdicional com o tempo necessário aos debates entre os litigantes, à investigação probatória e ao amadurecimento da convicção judicial”.
} 
Quando se fala em eficácia dos direitos fundamentais e em efetividade do processo, atualiza-se a lição centenária de Chiovenda, complementada por Barbosa Moreira, de que a justiça deve dar ao titular do direito tudo aquilo a que ele tem direito de acordo com o ordenamento, com o menor dispêndio de tempo, de custo e de atividade humana.

Não obstante as elucidações doutrinárias trazidas acima, que por si só já dão conta da existência de uma garantia fundamental à efetiva tutela jurisdicional, decorrente da própria fundamentalidade do direito de ação ou direito ao processo digno (CARVALHO, 2018), que “aponta para a especial dignidade de protecção dos direitos num sentido formal e num sentido material" (CANOTILHO, 2003, p. 378), a abertura material do catálogo de direitos fundamentais ${ }^{3}$, viabilizada pelo art. $5^{\circ}, \S 2^{\circ}$, da $\mathrm{CF}$, permite chegar a tal conclusão.

Apesar de não expressamente prevista na Constituição de 1988 (desprovida de fundamentalidade formal, portanto), a garantia à efetividade da prestação jurisdicional possui evidente fundamentalidade material ${ }^{4}$, compreendendo um princípio constitucional implícito, uma vez que decorre logicamente de outros direitos e garantias fundamentais positivados no texto constitucional, como o devido processo legal (art. $\left.5^{\circ}, \mathrm{LIV}\right)^{5}$.

Marinoni (2007b, p. 220), ao discorrer sobre o tema, sintetiza que do direito ao processo (art. $5^{\circ}, \mathrm{XXXV}, \mathrm{CF}$ ) extrai-se a garantia de que a resposta do Estado à pretensão autoral deverá ser efetiva - mesmo no caso de julgamento de improcedência -, trazendo, ainda, duas dimensões da efetividade: lato e stricto sensu, sendo esta a que mais de perto interessa ao presente artigo, encarada como preordenação dos meios executivos aptos a garantir a realização da decisão judicial no mundo sensível dos fatos.

Sobre o tema, Couture (1998, p. 89) assinala que "el contenido de la jurisdición no se reduce a la actividad cognoscitiva de la misma sino también a su actividad ejecutiva". E continua o processualista uruguaio

Conocimento y declaración sin ejecución es academia y no justicia; ejecución sin conocimento es despotismo y no justicia. Sólo un perfecto equilibrio entre las

\footnotetext{
3 Sobre a abertura material do catálogo de direitos fundamentais e os assim denominados princípios constitucionais implícitos, consultar: Sarlet (2015, p. 78-140).

${ }^{4}$ Acerca da dupla fundamentalidade - material e formal - dos direitos, ver: Sarlet (2015, p. 74-78).

${ }^{5}$ Didier Júnior (2016, p. 113) afiança que o princípio da efetividade ou direito fundamental à efetividade pode ser extraído tanto da cláusula geral do devido processo legal (5., LIV, CF), quanto do princípio da inafastabilidade $\left(5^{\circ} ., \mathrm{XXXV}, \mathrm{CF}\right)$.
} 
garantías del examen del caso y las possibilidades de hacer efectivo el resultado de ese examen, da a la jurisdicción su efectivo sentido de realizadora de la justicia (COUTURE, 1998, p. 89).

Em solo brasileiro, ao identificar o problema da inefetividade do processo civil, Moreira (1984, p. 27-28) identificou cinco pressupostos para um efetivo processo, quais sejam

a) o processo deve dispor de instrumentos de tutela adequados, na medida do possível, a todos os direitos (e outras posições jurídicas de vantagem) contemplados no ordenamento, quer resultem de expressa previsão normativa, quer se possam inferir do sistema; b) esses instrumentos devem ser praticamente utilizáveis, ao menos em princípio, sejam quais forem os supostos titulares dos direitos (e das outras posições jurídicas de vantagem) de cuja preservação ou reintegração se cogita, inclusive quando indeterminado ou indeterminável o círculo dos eventuais sujeitos; c) impende assegurar condições propícias à exata e completa reconstituição dos fatos relevantes, a fim de que o convencimento do julgador corresponda, tanto quanto puder, à realidade; d) em toda a extensão da possibilidade prática, o resultado do processo há de ser tal que assegure à parte vitoriosa o gozo pleno da específica utilidade a que faz jus segundo o ordenamento; e) cumpre que se possa atingir semelhante resultado com o mínimo de dispêndio de tempo e energias.

Não é suficiente para a realização do direito fundamental a um processo efetivo que o mesmo siga o roteiro das demais garantias constitucionais, como o efetivo contraditório, ampla defesa e fundamentação das decisões, se, ao final, após o longo embate no processo de conhecimento e sagrando-se vencedor, não lhe é assegurada, em um espaço de tempo razoável (item “e”), a satisfação material da ordem judicial que lhe favorece (item "d").

Advertindo que a efetiva tutela dos direitos não se dá sem a previsão de meios executivos idôneos, Marinoni (2016, p. 127-128) assim se posiciona:

Acontece que a sentença que reconhece a existência de um direito, mas não é suficiente para satisfazê-lo, não é capaz de expressar uma prestação jurisdicional efetiva, uma vez que não tutela o direito e, por isso mesmo, não representa uma resposta que permita ao juiz se desincumbir do seu dever perante a sociedade e os direitos. Diante disso, não há dúvida que a tutela jurisdicional só se aperfeiçoa, nesses casos, com a atividade executiva. Portanto, a jurisdição não pode significar mais apenas "iuris dictio" ou "dizer o direito", como desejavam os juristas que enxergam na atividade de execução uma mera função administrativa ou uma "função menor". Na verdade, mais do que direito à sentença, o direito de ação, hoje, tem como corolário o direito ao meio executivo adequado [grifo do autor]. 
A íntima relação entre efetividade do processo e meios executivos já havia sido identificada há muito na doutrina italiana. O jurista italiano Michelle Taruffo, citado por Abreu (2012, p. 72-73), já chamava a atenção, em 1988, para a questão:

[...] è sempre piú evidente, infatti, che l’efficacia della tutela giurisdizionale in generale, e la stessa esistenza dei 'nuovi diritti' che vanno arricchendo Il catalogo delle situazioni di vantagio, sono strettamente condizionate dalla strutura e dalloperatività del sistema della tutela esecutiva.

Nessa ótica, um Estado Democrático de Direito deve assegurar ao jurisdicionado não apenas o recurso ao Poder Judiciário, ou ainda que o processo irá se desenvolver oportunizando-lhe um efetivo contraditório, ampla defesa, decisão justa e fundamentada no direito vigente e meios de impugnação das decisões, mas, mais do que isso, deve garantir ao vencedor da demanda a realização fática do que lhe fora assegurado em sentença, a conversão do comando judicial no bem da vida almejado, enfim, a satisfação em um espaço de tempo que permita a justa fruição pelo seu titular.

Tida por Carneiro (2014, p. 91) como o verdadeiro "calcanhar de aquiles" da função jurisdicional, para Didier Júnior (2016, p. 80) a solução adequada ao tormento que assola a efetividade do processo civil brasileiro, em relação ao cumprimento/execução das decisões judiciais, parte do reconhecimento de um direito fundamental à tutela executiva, a qual deve ser efetiva e prestada dentro de um tempo razoável.

Corroborando a natureza jusfundamental da garantia aos meios executórios - como corolário da garantia ao processo efetivo stricto sensu - com seus devidos consectários (plena vigência, aplicação imediata e poder vinculativo em relação a todas as esferas do Estado), Guerra (1999, p. 57), além de prever a necessidade de um sistema legislativo apto a tal desiderato, assenta que a atividade jurisdicional deve ser pautada nos seguintes comandos hermenêuticos:

a) o juiz tem o poder-dever de negar a aplicação de qualquer restrição imposta por norma infraconstitucional que limite o uso de meios executivos (sub-rogatórios e coercitivos) de maneira a comprometer-lhes a eficácia; b) na prestação da tutela executiva, nas questões que envolvam o cabimento e a escolha de meio executivo mais adequado à execução forçada do direito, o juiz, ao resolvê-las, deve ter presente o princípio da interpretação conforme a Constituição, o que implica adequar, o máximo possível, os resultados práticos ou concretos da decisão às exigências de garantia dos direitos fundamentais em jogo; c) o juiz tem o poder- 
dever de, mesmo e principalmente no silêncio da lei, determinar os meios executivos que se revelem necessários para melhor atender à exigência de prestação de tutela executiva eficaz.

Canotilho (2003) reforça a tese ao defender a existência de um direito à execução das decisões dos tribunais, pressuposto de uma protecção jurídica eficaz, extensiva inclusive às sentenças proferidas contra o próprio Estado. Logo, não se cogita um processo justo, devido processo legal ou, ainda, processo digno, entendido como aquele prometido pela Constituição, sem efetividade, a qual, em sentido estrito, resta na dependência de um aparelhamento do sistema jurídico com meios executivos idôneos à materialização do resultado do processo em um menor espaço de tempo possível, exigindo ainda posicionamento do Judiciário pautado em critérios hermenêuticos voltados à máxima efetividade dos direitos, inclusive no espectro executivo.

Ainda sobre o ponto, corroborando a existência do direito fundamental à tutela executiva efetiva e tempestiva, Silva $(2017$, p. 1) pondera que

\begin{abstract}
A concepção de direito de ação como direito à sentença de mérito não poderia ter vida muito longa, uma vez que o julgamento do mérito somente tem importância como deveria ser óbvio - se o direito material envolvido no litígio for realizado além de reconhecido pelo Estado-Juiz. Nesse sentido, o direito à sentença deve ser visto como direito ao provimento e aos meios executivos capazes de dar efetividade ao direito substancial, o que significa direito à efetividade em sentido estrito.

Mas, não há como esquecer, quando pensamos no direito à efetividade em sentido lato, de que a tutela jurisdicional deve ser tempestiva e, em alguns casos ter a possibilidade de ser preventiva.
\end{abstract}

Mesmo sob a vigência do revogado Código Buzaid, Cambi (2009, p. 231) já endossava a tese de que a partir do direito de ação (art. $5^{\circ}$., XXXV, CF), reforçado pela garantia de duração razoável do processo (art. $5^{\circ}$., LXXVIII, CF), poder-se-ia extrair um "direito fundamental à efetiva tutela executiva", exigindo-se "esforço interpretativo no sentido de compatibilizar a interpretação das regras processuais com a Constituição”.

Assim, comprometido com tal desiderato, o CPC/2015 incluiu como uma das normas fundamentais e verdadeiro vetor interpretativo a garantia da satisfatividade da prestação jurisdicional, dispondo no art. $4^{\circ}$. que "as partes têm o direito de obter em prazo razoável a solução integral do mérito, incluída a atividade satisfativa", consignando, agora de forma expressa, que as ideias de efetividade e duração razoável do processo não se restringem à fase 
cognitiva, mas devem igualmente ser observadas na tutela executiva, tudo isso com o status de norma fundamental do processo civil.

\section{CUMPRIMENTO DE SENTENÇA PECUNIÁRIA EM FACE DA FAZENDA PÚBLICA NO NOVO CPC}

Com a vigência do novo Código de Processo Civil, instituído pela Lei n. 13.105/2015, buscando dar um passo rumo à efetividade da tutela jurisdicional, algumas mudanças foram implementadas na sistemática legal da execução por quantia certa em face da Fazenda Pública arrimada em título judicial.

Prima facie, ganha destaque a adoção do sincretismo nas execuções de títulos judiciais em desfavor da Fazenda Pública, que finalmente chegou aos processos movidos em face do Estado - e na execução de alimentos também - atendendo a uma parte dos reclamos da doutrina ${ }^{6}$, que considerava desarrazoado benefício ao Poder Público em juízo manter o antigo sistema dual de processo de conhecimento e processo de execução.

A alteração trazida pelo novo CPC já se apresenta no título do capítulo destinado ao tratamento da matéria: Do Cumprimento de Sentença que Reconheça a Exigibilidade de Obrigação de Pagar Quantia Certa pela Fazenda Pública, encerrando os artigos 534 e 535, em substituição ao anterior Da Execução Contra a Fazenda Pública, que subsiste no art. 910, mas agora somente aplicável quando se tratar de execução com base em título extrajudicial, adiante detalhado. De toda sorte, agora existem dois regramentos distintos: um para execuções de títulos judiciais - agora nomeadamente fase de cumprimento - e outro para execuções aparelhadas em títulos extrajudiciais, operacionalizadas via processo autônomo de execução.

\subsection{CUMPRIMENTO DE SENTENÇA QUE RECONHEÇA A EXIGIBILIDADE DE OBRIGAÇÃO DE PAGAR QUANTIA CERTA PELA FAZENDA PÚBLICA}

\footnotetext{
${ }^{6}$ Câmara (2009, p. 150), por exemplo, referindo-se à nova sistemática implementada pela Lei n. 11.232/05 e a sua não aplicação às execuções contra a Fazenda Pública, afirma que "trata-se de mais uma demonstração de como o direito processual brasileiro superprotege o Poder Público, conferindo-lhe uma série de privilégios absolutamente inaceitáveis".
} 
Disciplinado nos artigos 534 e 535 do CPC/2015, o procedimento de cumprimento de sentenças judiciais que condenam o Estado ao pagamento de quantia certa se inicia sempre a requerimento do credor, logo após o trânsito em julgado da decisão condenatória.

Não obstante os requisitos formais do demonstrativo do débito que deve acompanhar a petição de cumprimento da sentença $\left(534, \S 1^{\circ}\right.$, do CPC/2015), a expressa previsão de fracionamento da execução, com demonstrativo individualizado para cada credor, se harmoniza com o atual entendimento do STJ sobre o tema, segundo o qual

\footnotetext{
$\mathrm{O}$ fracionamento vedado pela norma constitucional toma por base a titularidade do crédito. Assim, um mesmo credor não pode ter seu crédito satisfeito por RPV e precatório, simultaneamente. Nada impede, todavia, que dois ou mais credores, incluídos no polo ativo da mesma execução, possam receber seus créditos por sistemas distintos (RPV ou precatório), de acordo com o valor que couber a cada qual.

Sendo a execução promovida em regime de litisconsórcio ativo voluntário, a aferição do valor, para fins de submissão ao rito da RPV (art. 100, § $3^{\circ}$ da CF/88), deve levar em conta o crédito individual de cada exequente. Precedentes de ambas as Turmas de Direito Público do STJ. (BRASIL, 2014, p. 1)
}

Dessa forma, o litisconsórcio multitudinário, comum em ações movidas contra a Administração, não representa um atentado à duração razoável do processo, podendo, na fase de cumprimento, ser o precatório fracionado, levando-se em consideração não o montante total, que comumente enseja a expedição de precatório, mas o valor individual de cada credor isoladamente considerado, autorizando, se for o caso, que alguns recebam por intermédio de pagamento de obrigação de pequeno valor, o que já revela alguma contribuição para a efetividade e duração razoável da prestação jurisdicional.

\subsection{DEFESA DA FAZENDA PÚBLICA: IMPUGNAÇÃO AO CUMPRIMENTO DE SENTENÇA}

Requerido pelo credor o cumprimento da sentença condenatória, devidamente instrumentalizado com o demonstrativo atualizado do débito, o ente executado será intimado não para pagar a dívida no prazo de 15 dias, como acontece no cumprimento de sentença contra particular, ou para opor embargos no prazo de 30 dias, como ocorre na execução de título extrajudicial contra a Fazenda Pública, mas para impugnar o cumprimento em 15 dias - 
equivocadamente no texto ainda para "impugnar a execução" - considerando-se que na nova sistemática o termo execução fica restrito ao procedimento destinado aos títulos extrajudiciais, apesar de ambas referirem-se à atividade jurisdicional executiva.

Ao contrário do que acontece nos embargos à execução fundada em título extrajudicial, nos quais a Fazenda executada poderá suscitar qualquer matéria de defesa que seria lícito alegar no processo de conhecimento (art. 910, §2º do CPC/2015), na impugnação ao cumprimento da sentença o código traça limites objetivos. Como se trata de execução de sentença, a defesa é restrita, não abrangendo matérias que foram ou deveriam ter sido alegadas na fase de conhecimento. O STJ inclusive já se manifestou pela taxatividade das hipóteses de cabimento de embargos à execução fundada em título executivo judicial ${ }^{7}$, entendimento este que deve ser mantido na vigência do novo ordenamento processual, agora em relação à impugnação ao cumprimento.

A impugnação pode versar sobre falta ou nulidade da citação, suposto que a fase de conhecimento tenha corrido à revelia; ilegitimidade de parte; excesso de execução (definida no art. 917, §2 , do CPC/2015) ou cumulação indevida de execuções; incompetência absoluta do juízo que proferiu a condenação, ou mesmo relativa, do juízo da execução; fato superveniente, modificativo ou extintivo da obrigação, posterior ao trânsito em julgado da sentença.

Novidade é a possibilidade expressa de parte da condenação não impugnada ser objeto de cumprimento imediato, não precisando aguardar o julgamento da impugnação (art. $535, \$^{\circ}$ ), expedindo-se desde logo o precatório ou requisição de pequeno valor, a depender do caso, afinando-se com a jurisprudência do $\mathrm{STJ}^{8}$, que entendem se tratar de verdadeira execução definitiva quanto à parcela incontroversa da condenação.

Como se viu, na sistemática do CPC/1973, a doutrina e os tribunais ${ }^{9}$ construíram entendimento no sentido de que o art. 100 da CF exigia dois trânsitos em julgado, um da decisão no processo de conhecimento (decisão condenatória) e outro da decisão que rejeitasse

\footnotetext{
7 “As hipóteses de cabimento de embargos contra execução fundada em título judicial são taxativas." (BRASIL. Superior Tribunal de Justiça. REsp 860342/CE, Relator: Min. Humberto Martins, 2006).

${ }^{8}$ BRASIL. Superior Tribunal de Justiça. Aglnt REsp 1618060/RS, Relator: Min. Mauro Campbell Marques, 2017c.

${ }^{9}$ A demonstrar o entendimento segundo o qual a apelação contra a sentença que rejeitava embargos oferecidos pela Fazenda Pública sempre seria dotado de duplo efeito: BRASIL. Superior Tribunal de Justiça. Aglnt REsp 1276037/PR, Relator: Min. Humberto Martins, 2012.
} 
os embargos à execução, trazendo assombrosa demora ao procedimento de execução, mesmo depois de concluído o processo de conhecimento, já que normalmente instaurava-se um novo processo de conhecimento sob o rótulo de embargos à execução, não raro com nova sequência de recursos, inclusive chegando aos tribunais superiores, obstando o trânsito e julgado e, portanto, a expedição da requisição de pagamento.

O Fórum Permanente de Processualistas Civis - FPPC, seguindo a mesma linha de entendimento, editou o enunciado n. 532 com a seguinte redação: “A expedição do precatório ou da RPV depende do trânsito em julgado da decisão que rejeita as arguições da Fazenda Pública executada".

Vem de Cunha (2016, p. 337) a justificativa de tal posicionamento, expondo as razões por detrás da tese dos dois trânsitos em julgado

\begin{abstract}
O trânsito em julgado a que se referem os $\S \S 3^{\circ}$ e $5^{\circ}$ do art. 100 da Constituição Federal é o da sentença que julgar a impugnação ao cumprimento da sentença ou os embargos à execução fundada em título extrajudicial. E isso porque o valor a ser incluído no orçamento deve ser definitivo, não pendendo qualquer discussão a seu respeito. Observe-se que toda lei orçamentária que é aprovada estabelece, em um de seus dispositivos, que somente incluirá dotações para o pagamento de precatórios cujos processos contenham certidão de trânsito em julgado da decisão exequenda e, igualmente, certidão de trânsito em julgado dos embargos à execução ou, em seu lugar, certidão de que não tenham sido opostos embargos ou qualquer impugnação aos respectivos cálculos.
\end{abstract}

Como visto, a tese do duplo trânsito em julgado se apoia unicamente na necessidade de definitividade do débito exequendo para expedição da requisição de pagamento. Indaga-se: onde pode ser encontrado tal requisito? Na Constituição Federal ou no novo Código de Processo Civil certamente não.

Porém, a despeito da inexistência de previsão constitucional ou no CPC, cumpre esclarecer que as leis de diretrizes orçamentárias geralmente trazem tal exigência ${ }^{10}$, não se revelando, entretanto, motivo idôneo para incluir nova exigência na sistemática constitucional dos precatórios, em especial quando a própria Constituição não o fez, sobretudo por se tratar

10 A Lei de Diretrizes Orçamentárias da União de 2018 (Lei 13.473/2017), por exemplo, traz o seguinte dispositivo: “Art. 26. A Lei Orçamentária de 2018 somente incluirá dotações para o pagamento de precatórios cujos processos contenham certidão de trânsito em julgado da decisão exequenda e pelo menos um dos seguintes documentos: I - certidão de trânsito em julgado dos embargos à execução; e II - certidão de que não tenham sido opostos embargos ou qualquer impugnação aos cálculos”. (BRASIL, 2017b, p. 1). 
de regra que restringe sobremaneira garantias fundamentais do jurisdicionado, como efetividade do processo e duração razoável, malferindo a ideia de dignidade processual.

Assim, o state of the art sobre a matéria pode se resumir da seguinte forma: a simples apresentação de impugnação pela Fazenda Pública suspende automaticamente o cumprimento da sentença e eventuais recursos interpostos posteriormente terão igual efeito suspensivo ope legis.

Bueno (2018, p. 538-539), em contrapartida, entende que o trânsito em julgado exigido pela Constituição no art. 100 não é e nem poderia ser o da decisão da impugnação. Segundo o autor

Para os $\S \$^{\circ}$., $3^{\circ}$. e $5^{\circ}$., do art. 100 da $\mathrm{CF}$, a decisão que dever ter transitado em julgado, na normalidade dos casos, para viabilizar o precatório ou a requisição de pequeno valor é (e só pode ser) a da etapa de conhecimento e não a da etapa de cumprimento, isto é, aquela a ser proferida em eventual impugnação apresentada pela Fazenda Pública. Tanto é assim que o próprio $\$ 3^{\circ}$. do art. 535 [do CPC/2015], em sua primeira parte, que reconhece a possibilidade de a impugnação não ser apresentada pela Fazenda Pública ou, ainda, o seu $\$ 4^{\circ}$. que se refere à hipótese de a impugnação ser parcial e a "parte não questionada pela executada" ser, "desde logo, objeto de cumprimento”.

Com a nova sistemática, para a expedição da requisição de pagamento, o trânsito em julgado só se apresenta indispensável para os embargos à execução lastreada em título extrajudicial, já que possuem evidente natureza jurídica de ação ${ }^{11}$, com abrangente espectro de matérias suscitáveis, havendo expressa menção à necessidade do trânsito em julgado da sentença que rejeita os embargos ${ }^{12}$, in casu, o primeiro e único trânsito, considerando a inexistência de prévia fase de conhecimento.

Entretanto, quanto aos títulos judiciais, oriundos de uma fase cognitiva bastante ampla, a oposição ao pedido de sua execução prescinde de nova ação (embargos), havendo apenas a necessidade de se oportunizar à Fazenda condenada o manejo de impugnação ao

\footnotetext{
${ }^{11}$ Conforme doutrina majoritária, os embargos à execução "constituem ação de conhecimento que resta por gerar um processo incidental e autônomo, através do qual o executado tem a oportunidade de impugnar a pretensão creditícia do exequente e a validade da relação processual executiva" (PINHO, 2017, p. 744). Não se olvida, entretanto, vozes que sustentam a natureza de defesa dos embargos, a exemplo de Bueno (2018). Há ainda autores que defendem a natureza dúplice dos embargos à execução, podendo ser de ação de conhecimento ou mera defesa incidental, a depender da matéria veiculada, nesse sentido: Medina (2017, p. 395;397).

12 “Art. 910. [...] $\S 1^{\circ}$ Não opostos embargos ou transitada em julgado a decisão que os rejeitar, expedir-se-á precatório ou requisição de pequeno valor em favor do exequente, observando-se o disposto no art. 100 da Constituição Federal” (BRASIL, 2015, p. 1).
} 
cumprimento, via incidental, com campo de discussão limitado e efeito suspensivo ope legis (nos termos do art. 535, $\S 3^{\circ}$, somente depois de transcorrido in albis o prazo de impugnação ou sendo esta rejeitada, a execução terá prosseguimento). Esse também é o entendimento de Marinoni, Arenhart e Mitidiero (2015, p. 1043):

Por outras palavras, e ao contrário do que sucede com o regime geral do CPC, aplicável a qualquer outro devedor, em relação à execução movida contra a Fazenda Pública, ainda que fundada em título judicial, a impugnação tem sempre efeito suspensivo, independentemente do preenchimento dos requisitos do art. 525, $\S 6^{\circ}$.

Advogando tese contrária - de que a impugnação eventualmente apresentada pela Fazenda Pública não tem efeito suspensivo automático - Bueno (2018, p. 539) assevera que

[...] é correto entender que cabe à Fazenda Pública requerer a concessão de efeito suspensivo à sua impugnação, hipótese em que deverá demonstrar ao magistrado a ocorrência dos pressupostos do $\S 6^{\circ}$. do art. 525. A única (e essencial) distinção com relação ao que ocorre no cumprimento de sentença regida por aquele dispositivo, esta, sim, perfeitamente harmônica com o "modelo constitucional", é que a Fazenda não fica sujeita a garantir o juízo.

Contudo, diferentemente do que ocorre nos embargos à execução, haja vista que a necessidade do trânsito em julgado da sentença que os rejeita implica na obrigatória suspensividade do recurso contra ela interposto (efeito suspensivo ope legis), o incidente de impugnação será resolvido por decisão interlocutória, atacável por agravo de instrumento, nos termos do art. 1.015, parágrafo único, dispensando-se a necessidade de trânsito em julgado da citada decisão para a continuidade da execução em seus ulteriores atos, pois o citado recurso não possui efeito suspensivo ope legis.

É o que se extrai do art. 535, $\S 3^{\circ}$, do CPC/2015, uma vez que, não impugnada a execução ou rejeitadas as arguições da executada, será expedida a requisição de pagamento. Com efeito, nesta situação o credor já teve seu direito certificado na fase de conhecimento e, portanto, já dispõe de sentença transitada em julgado, atendendo, assim, à exigência constitucional do art. $100, \S 5^{\circ}$ da $\mathrm{CF} / 88$, não sendo razoável, agora em sede de cumprimento de sentença, instaurar-se nova fase cognitiva, com novos recursos dotados de suspensividade, capaz de obstar a realização do direito material assegurado ao jurisdicionado, frustrando talvez a mais substancial inovação rumo à dignidade processual nesta seara. 
Ora, quando o legislador quis impor o trânsito em julgado da decisão que rejeita a ação/defesa do devedor como exigência para a expedição do precatório, ele o fez de maneira expressa, a teor do art. $910, \S 1^{\circ}$, do CPC/2015. Não se pode simplesmente tachar de lapso o fato de o legislador não ter inserido previsão idêntica no capítulo de cumprimento de sentença. É preciso se fazer o cotejo entre os dois regramentos (cumprimento de sentença e execução de título extrajudicial), e todo o sistema processual, para então, a partir daí extrairse a norma que melhor se adeque à ideia de processo digno, aqui defendida.

Corroborando a tese que ora se sustenta - desnecessidade do trânsito em julgado da decisão que rejeita a impugnação para a expedição de requisição de pagamento - existe o fato de que o Projeto de Lei do Senado n. 166/2010, com as alterações apresentadas no relatóriogeral do Senador Valter Pereira (BRASIL, 2010a), que deu origem ao CPC/2015, disciplinava a matéria ora tratada (cumprimento de sentença em face da Fazenda Pública) nos artigos 519 e 520, chamando a atenção a redação original do artigo que abria a disciplina (art. 519): “Art. 519. Transitada em julgado a sentença que impuser à Fazenda Pública o dever de pagar quantia certa, ou, se for o caso, a decisão que julgar a liquidação, o exequente apresentará demonstrativo discriminado e atualizado do crédito [...]."

Percebe-se, na redação original, a expressa referência à necessidade de trânsito em julgado da decisão que julgar a liquidação, o que foi retirado na redação definitiva do dispositivo (hoje art. 534). Tal opção certamente revela uma posição do legislador sobre o tema: não é necessário o trânsito em julgado da impugnação para expedição do precatório.

Nesse ponto, vale transcrever a advertência de Theodoro Júnior et al. (2015, p. 13):

\begin{abstract}
Assim, o Novo CPC somente pode ser interpretado a partir de suas premissas, de sua unidade, e especialmente de suas normas fundamentais, de modo que não será possível interpretar/aplicar dispositivos ao longo de seu bojo sem levar em consideração seus princípios e sua aplicação dinâmica (substancial).

Ademais, não será possível analisar dispositivos de modo isolado, toda compreensão deve se dar mediante o entendimento pleno de seu sistema, sob pena de se impor leituras apressadas e desprovidas de embasamento consistente.
\end{abstract}

Logo, trazer a exigência do trânsito de julgado da decisão que rejeitar a impugnação onde o próprio legislador não o fez, promovendo uma interpretação isolada do art. $535, \S 3^{\circ}$, do CPC/2015, revela-se opção descomprometida com garantias processuais fundamentais do jurisdicionado. 


\subsection{IMPOSSIBILIDADE DE ATRIBUIÇÃO DE EFEITO SUSPENSIVO OPE LEGIS AO AGRAVO DE INSTRUMENTO CONTRA DECISÃO QUE REJEITA A IMPUGNAÇÃO APRESENTADA PELA FAZENDA PÚBLICA}

Inobstante os aclaramentos sobre a sistemática implementada pelo CPC/2015, máxime a prescindibilidade do trânsito em julgado da decisão que rejeita a impugnação ao cumprimento de sentença para a continuidade deste, expedindo-se desde logo a requisição de pagamento, surge uma questão crucial à efetivação do processo digno no âmbito da execução contra a Fazenda Pública: a possibilidade da atribuição de efeito suspensivo ao agravo de instrumento interponível contra a citada decisão.

O artigo 1.015 do CPC/2015 traz as decisões interlocutórias que desafiam agravo de instrumento, constando, dentre elas, aquelas proferidas na fase de cumprimento da sentença, caso do ato judicial que rejeita a impugnação ora tratada. $\mathrm{O}$ ato que acolhe as alegações da Fazenda impugnante, também decisão interlocutória e agravável, não traz tanta importância ao presente artigo, uma vez que neste caso, a execução terá seu prosseguimento obstado.

Como visto linhas acima, o legislador optou por atribuir à impugnação apresentada pela Fazenda Pública um inarredável efeito suspensivo, com o qual não se discorda, razão pela qual apenas no caso de não impugnação no prazo ou se forem "rejeitadas as arguições da executada", poderá, incontinenti, ser expedido o precatório ou requisição de pequeno valor, ainda que a decisão esteja sujeita a recurso (embargos de declaração ou agravo de instrumento). Este também é o entendimento esposado por Marinoni, Arenhart e Mitidiero (2017)..$^{13}$

Dessa forma, apesar do tratamento diferenciado que ainda pode deixar transparecer uma proteção exacerbada à Fazenda Pública - na regra geral, a impugnação tem efeito suspensivo ope juris, que só será deferido nas situações do art. 525, §6 ${ }^{\circ}$ do CPC/2015 - o sincretismo trouxe avanço em termos de dignidade processual na execução contra a Fazenda

\footnotetext{
${ }^{13}$ Segundo os autores, "Assim, somente a parte incontroversa - ou seja, a parte sobre a qual não recair impugnação - é que poderá ser desde logo realizada, com a expedição do precatório requisitório ou da requisição correspondentes. Quanto ao restante, somente depois da decisão da impugnação - ainda que sujeita a recurso - é que poderá a execução seguir, com a expedição do precatório ou da requisição cabíveis" (MARINONI, ARENHART; MITIDIERO, 2017, p. 1043).
} 
Pública: o credor não precisa esperar mais novo trânsito em julgado (já existe o trânsito em julgado da decisão condenatória, cumprindo, portanto, a exigência constitucional) para a expedição da ordem de pagamento.

Não se defende aqui a total impossibilidade de atribuição de efeito suspensivo ao agravo de instrumento interposto contra decisão que rejeita a impugnação apresentada pelo Estado, mas apenas que isso não pode ocorrer de forma automática, ante a ausência de previsão legal, ficando condicionada tal medida a um juízo de viabilidade realizado pelo Relator e desde que preenchidos os requisitos legais.

$\mathrm{O}$ CPC/2015, ao disciplinar o agravo de instrumento, que continua com o processamento semelhante ao sistema do CPC/1973, prevê que o relator poderá lhe atribuir efeito suspensivo (art. 1.019), nas hipóteses previstas no art. 995, parágrafo único. Todavia, no caso da execução contra a Fazenda Pública por título judicial, após processo de cognição exauriente, o prosseguimento da execução, com expedição de precatório, em regra, uma vez que já delimitada a condenação, não traz, a priori, qualquer dano grave, de difícil ou impossível reparação ao erário, salvo em casos de abusos do exequente, hipótese em que restará resguardada a possibilidade de atribuição de efeito suspensivo ope iudicis.

Ao revés, defender que sempre será necessário atribuir efeito suspensivo, para aguardar o julgamento do agravo e, provavelmente, outros meios de impugnação utilizados à exaustão pelo Estado, é que se teria o condão de atingir o núcleo essencial do direito fundamental ao processo digno conferido ao cidadão, que, não raro nesses casos, vai a óbito aguardando receber "seu precatório", cujo prazo de pagamento em algumas situações, somado ao processo de conhecimento, supera décadas. ${ }^{14}$

Em verdade, nessa situação, já milita a favor do credor uma sentença passada em julgado (que certificou o direito e já é indiscutível) e uma decisão na fase de cumprimento que rejeitou as arguições da executada, revelando-se medida desproporcional fazê-lo esperar pelo final de mais um procedimento, aplicando-se as mesmas regras de contraditório, instrução e recursos previstas para a fase de conhecimento. Esse entendimento poderia ser empregado nos embargos à execução do CPC/1973, porquanto configuravam verdadeira ação autônoma, mas

\footnotetext{
${ }^{14}$ Conforme levantamento realizado pela OAB/SP, ainda em 2009, mais de 60 mil credores em condenações judiciais contra o estado de São Paulo já haviam morrido na fila de espera, sem receber o que lhes foi assegurado pelo Judiciário. (OAB SÃO PAULO, 2009).
} 
definitivamente não se ajustam à nova fase cumprimento de sentença e sua respectiva impugnação, agora endoprocessual.

Nesta mesma linha de raciocínio, por meio de interpretação sistemática ${ }^{15}$ do regramento do cumprimento de sentença em relação à execução de título extrajudicial, ambos por quantia certa em face da Fazenda Pública, fica evidente o desígnio legislativo, ao criar dois sistemas distintos, a depender do título que o embasa. Na execução por quantia certa, com base em título extrajudicial, optou o legislador por manter os embargos como verdadeira ação judicial e igualmente indispensável o trânsito em julgado a decisão que os rejeitar, com expressa previsão no art. $910, \S 1^{\circ}$. Todavia, no cumprimento da sentença, que, por já se encontrar trânsita em julgado e gozar de inegável estabilidade, proporcionada pela cognição exauriente na fase anterior, já estaria apta a surtir seus efeitos, não havendo necessidade de nova imutabilidade da decisão que rejeita a impugnação.

É de se concluir, portanto, que caso os tribunais mantenham o posicionamento de atribuir efeito suspensivo ope legis aos agravos interpostos pela Fazenda Pública contra as decisões que rejeitarem as respectivas impugnações, as citadas inovações legislativas e as expectativas dos litigantes contra o Estado, assim como de parte da academia, restariam frustradas, pois o sistema, apesar dos novos dispositivos, continuaria funcionando com as mesmas normas ${ }^{16}$ do CPC/1973 e sob as premissas do velho sistema, que, como já visto, não atendem às necessidades do que hoje se entende por processo digno.

Percebe-se, assim, o esforço do legislador para implementar regras que busquem a realização do direito fundamental ao processo digno na seara da execução contra a Fazenda Pública, identificando-se na sistemática trazida pelo CPC/2015 algum potencial para avançar, a depender da sua apreensão e aplicação pelo Judiciário, que tem o poder de dar vida ao espírito do CPC/2015, mas também pode abortar o esforço empregado na sua elaboração.

\section{CONSIDERAÇÕES FINAIS}

Como visto, a entrada em vigor do novo Código de Processo Civil (Lei 13.105/15) representou a sedimentação do fenômeno da constitucionalização do direito processual civil,

\footnotetext{
${ }^{15}$ Segundo o professor Freitas (2004, p. 62), toda interpretação é sistemática ou não é interpretação.

${ }^{16}$ Sobre a distinção entre texto e norma, em que esta é o resultado da interpretação daquele, consultar: Guastini (2005).
} 
devendo este ser lido a partir dos valores e normas fundamentais consagrados pela Constituição Federal (art. 1 ${ }^{\circ}, \mathrm{CPC} / 15$ ), dentre os quais se encontram, indubitavelmente, as garantias de efetividade da prestação jurisdicional e duração razoável do processo, de onde se pode extrair, como visto, uma garantia igualmente fundamental à tutela executiva efetiva e tempestiva.

Nessa ótica, mirando tal efetividade, o legislador trouxe inovações no procedimento de cumprimento de sentenças que condenam ao pagamento de quantia certa em face da Fazenda Pública, as quais, não obstante o "engessamento" constitucional da matéria, revelamse de alguma utilidade para tal desiderato. Uma delas, especialmente abordada no presente artigo: a possibilidade de continuidade da fase de cumprimento, com expedição da requisição de pagamento, imediatamente após a decisão que rejeita a impugnação ao cumprimento de sentença apresentado pela Fazenda Pública executada.

Porém, importa ressaltar que tais alterações não têm o condão de, por si só, provocarem os efeitos concretos que delas se esperam, fazendo-as eficazes, portanto. Faz-se necessário o engajamento da doutrina e comprometimento dos juízes no sentido de implementar uma hermenêutica concretizadora das garantias processuais fundamentais do cidadão nessa seara, o que, na questão especificamente enfrentada aqui, demandaria uma virada interpretativa acerca da (des)necessidade do trânsito em julgado da decisão que rejeita a impugnação para continuidade da execução em desfavor da Fazenda Pública, objetivando a concretização do direito fundamental do credor à tutela jurisdicional executiva efetiva e prestada em tempo razoável. Em breve, certamente a matéria chegará ao Superior Tribunal de Justiça para apreciação.

\section{REFERÊNCIAS}

ABREU, Laura Sirangelo Belmonte. Multa coercitiva (arts. 461 e 461-A, CPC): uma abordagem à luz do direito fundamental à tutela jurisdicional efetiva. In: MITIDIERO, Daniel (coord.). O processo civil no Estado Constitucional. Salvador: Juspodivm, 2012.

BRASIL. Código de Processo Civil. Lei no 13.105, de 16 de março de 2015. Disponível em: <http://www.planalto.gov.br/ccivil_03/_Ato2015-2018/2015/Lei/L13105.htm>. Acesso em: 01 abr. 2019 
BRASIL. Lei de Diretrizes Orçamentárias. Lei n⿳ 13.473, de 8 de agosto de 2017 b.

Disponível em: <http://www.planalto.gov.br/ccivil_03/_Ato2015-

2018/2017/Lei/L13473.htm>. Acesso em: 10 mar. 2019.

BRASIL. Senado Federal. Minuta Parecer n. xx, de 2010a. Disponível em <http://legis.senado.leg.br/sdleg-getter/documento?dm=4550612\&disposition=inline>. Acesso em: 20 mar.2018.

BRASIL. Superior Tribunal de Justiça. Agravo em Recurso Especial 1276037/PR. Relator: Min. Humberto Martins. Brasília, 19 abr. 2012. Disponível em: $<$ https://ww2.stj.jus.br/processo/revista/documento/mediado/?componente=ITA\&sequencial= $1135545 \&$ num_registro $=201102119703 \&$ data $=20120419 \&$ formato=PDF $>$. Acesso em: 2 abr. 2019.

BRASIL. Superior Tribunal de Justiça. Agravo em Recurso Especial 1618060/RS. Relator: Min. Mauro Campbell Marques. Brasília, 23 maio 2017c. Disponível em:

$<\mathrm{https}: / / \mathrm{ww} 2$. stj.jus.br/processo/revista/documento/mediado/?componente=ITA\&sequencial= $1605506 \&$ num_registro $=201601911054 \&$ data $=20170523 \&$ formato $=P D F>$. Acesso em: 2 abr. 2019.

BRASIL. Superior Tribunal de Justiça. Recurso Especial 860342/CE. Relator: Min. Humberto Martins. Brasília, 22 set. 2006. Disponível em:

<https://ww2.stj.jus.br/processo/revista/documento/mediado/?componente=ITA\&sequencial= 646332\&num_registro=200601259289\&data=20060922\&formato=PDF $>$. Acesso em: 2 abr. 2019.

BRASIL. Superior Tribunal de Justiça. Recurso Especial 1347736/RS. Relator: Min. Castro Meira. Brasília, 15 abr. 2014. Disponível em:

<https://www.lexml.gov.br/urn/urn:lex:br:superior.tribunal.justica;secao.1:acordao;resp:201310-09;1347736-1345123>. Acesso em: 2 abr. 2019.

BUENO, Cassio Scarpinella. Manual de direito processual civil. 4. ed. São Paulo: Saraiva, 2018.

CÂMARA, Alexandre Freitas. A nova execução de sentença. 6. ed. Rio de Janeiro: Lumen Juris, 2009.

CAMBI, Eduardo. Direito fundamental à efetiva tutela executiva. In: SHIMURA, Sérgio; BRUSCHI, Gilberto Gomes (coord.). Execução civil e cumprimento da sentença. v. 3. São Paulo: Método, 2009. p. 229-250.

CANOTILHO, J. J. Gomes. Direito constitucional e teoria da constituição. 7. ed. 11 reimp. Coimbra: Almedina, 2003.

CARNEIRO, Athos Gusmão. A dualidade conhecimento/execução e o Projeto de novo Código de Processo Civil. In: ALVIM, Arruda et al.(coord.). Execução civil e temas afins do CPC/1973 ao Novo CPC. São Paulo: Revista dos Tribunais, 2014. 
CARVALHO, Fabrício de Farias. A execução em face da Fazenda Pública: dignidade e processo. Porto Alegre: Livraria do Advogado, 2018.

COUTURE, Eduardo J. Estudios de derecho processual civil: la Constitución y el processo civil. Tomo I. 3. ed. Buenos Aires: Depalma, 1998.

CUNHA, Leonardo Carneiro da. A Fazenda Pública em juízo. 13. ed. Rio de Janeiro: Forense, 2016.

DIDER JÚNIOR, Fredie. Curso de direito processual civil - volume 1. 16. ed. Salvador: JusPodivm, 2014.

DIDIER JÚNIOR, Fredie. Curso de direito processual civil. v. 1, 18. ed. Salvador: Jus Podivm, 2016.

FREITAS, Juarez. A interpretação sistemática do direito. 4. ed. São Paulo: Malheiros, 2004.

GRECO, Leonardo. Novas perspectivas da efetividade e do garantismo processual. In: MITIDIERO, Daniel; AMARAL, Guilherme Rizzo (coords.). Processo civil: estudos em homenagem ao professor doutor Carlos Alberto Alvaro de Oliveira. São Paulo: Atlas, 2012. p. 273-308.

GUASTINI, Riccardo. Das fontes às normas. Tradução de Edson Bini. São Paulo: Quartier Latin, 2005.

GUERRA, Marcelo Lima. Execução indireta. São Paulo: RT, 1999.

JOBIM, Marco Félix. O direito à duração razoável do processo. 2. ed. Porto Alegre: Livraria do Advogado, 2012.

MARINONI, Luiz Guilherme. Abuso de defesa e parte incontroversa da demanda. São Paulo: RT, 2007a.

MARINONI, Luiz Guilherme. Curso de Processo Civil, vol. I - Teoria Geral do Processo. São Paulo: RT, 2007b.

MARINONI, Luiz Guilherme. Novo curso de processo civil: teoria geral do processo. 2. ed. São Paulo: RT, 2016.

MARINONI, Luiz Guilherme; ARENHART, Sérgio Cruz; MITIDIERO, Daniel. Novo curso de processo civil - vol. II. São Paulo: RT, 2015.

MARINONI, Luiz Guilherme; ARENHART, Sérgio Cruz; MITIDIERO, Daniel. Novo curso de processo civil: teoria do processo civil. v. 1, 3. ed. São Paulo: RT, 2017.

MEDINA, José Miguel Garcia. Execução: teoria geral, princípios fundamentais e procedimento no processo civil brasileiro. 5. ed. São Paulo: RT, 2017.

MORAES, Alexandre. Constituição do Brasil interpretada e legislação constitucional. 5. ed. São Paulo: Atlas, 2005. 
MOREIRA, José Carlos Barbosa. Notas sobre o problema da "efetividade" do processo. In: Temas de direito processual: terceira série. São Paulo: Saraiva, 1984.

NICOLITTI, André. A duração razoável do processo. 2. ed. São Paulo: RT, 2014.

OAB SÃO PAULO. OAB SP quer reverter no senado aprovação à PEC dos precatórios. 2009. Disponível em: <http://www.oabsp.org.br/noticias/2009/11/27/5834>. Acesso em: 30 abr. 2015.

PINHO, Humberto Dalla Bernardina de. Direito processual civil contemporâneo: processo de conhecimento, procedimentos especiais, processo de execução, processo nos tribunais e disposições finais e transitórias. v. 2. 4. ed. São Paulo: Saraiva, 2017.

RIBEIRO, Darci Guimarães. Da tutela jurisdicional às formas de tutela. Porto Alegre: Livraria do Advogado, 2010.

SARLET, Ingo Wolfgang. A eficácia dos direitos fundamentais. 12. ed. Porto Alegre: Livraria do Advogado, 2015.

SILVA, Jaqueline Mielke. Os novos mecanismos de efetivação do direito fundamental à tutela jurisdicional executiva efetiva e tempestiva previstos no NCPC (Lei 13.105/15).

Revista Novos Estudos Jurídicos, Itajaí, v. 22, n. 01, jan./abr. 2017. Disponível em: <https://siaiap32.univali.br/seer/index.php/nej/article/view/10630>. Acesso em: 10 fev 2019.

THEODORO JÚNIOR, Humberto. Processo de execução e cumprimento da sentença. 28. ed. São Paulo: LEUD, 2014.

THEODORO JÚNIOR, Humberto; NUNES, Dierle; BAHIA, Alexandre Melo Franco; PEDRON, Flávio Quinaud. Novo CPC - fundamentos e sistematização. Rio de Janeiro: Forense, 2015.

TUCCI, José Rogério Cruz e. Garantia do processo sem dilações indevidas. In: (org.), Garantias constitucionais do processo civil, homenagem aos 10 anos da Constituição Federal de 1988. São Paulo: Revista dos Tribunais, 1998. p. 234-262.

WAMBIER, Luiz Rodrigues; WAMBIER, Teresa Arruda Alvim; MEDINA, José Miguel Garcia. Breves comentários à nova sistemática processual civil. 3. ed. São Paulo: RT, 2005. 